$\mathrm{J}$-Kesmas

Jurnal Kesehatan Masyarakat

\title{
FAKTOR YANG MEMENGARUHI PEMANFATAN JAMBAN KELUARGA DI DESA KARAMA KECAMATAN TINAMBUNG KABUPATEN POLEWALI MANDAR
}

\author{
Taslim ${ }^{1,}$ dan Patmawati ${ }^{2}$ \\ ${ }^{1}$ Kampus Universitas Al Asyariah Mandar, Fakultas Kesehatan Masyarakat. \\ Jl. Budi Utomo No.2 Manding, Kecamatan Polewali, Kabupaten Polewali Mandar, Provinsi Sulawesi \\ Barat, Indonesia. \\ E-mail: TaslimKaramain@gmail.com
}

\begin{abstract}
ABSTRAK
Tingginya mengenai kurangnya pemanfaatan jamban keluarga di Desa Karama Kecamatan Tinambung Kabupaten polewali Mandar di sebabkan karena faktor tradisi atau kebiasaan masyarakat Buang Air Besar di pantai, dan faktor pemahaman masih sangat rendah dan lingkungan yang sangat dekat dengan pingir pantai. Sehingga masyarakat yang ada di Desa Karama lebih membiasakan diri Buang Air Besar di pantai dari pada WC.Jenis penelitian ini adalah kaulitatif dengan wawancara mendalam (indepth interview) dengan penentuan sampel dipilih secara purposive sampling untuk menggali informasi lebih mendalam tentang pemamfaan jamban keluarga.Hasil penelitian ini menunjukan bahwa Ras (suku mandar) mengenai jamban keluarga mereka sudah memunyai pengetahuan tetapi masih sangat rendah mengenai pemamfatan jamban keluarga,fungsi jamban dan dampak yang di timbulkan oleh kotoran. Tetapi dengan faktor tradisi atau kebiasaan mereka lebih memilih Buang Air Besar di pantai dari pada WC karena membuat mereka lebih nyaman.
\end{abstract}

Kata kunci: Pemanfaan jamban keluarga, Tradisi,Ras.

\section{PENDAHULUAN}

Visi Indonesia sehat 2015. Gambaran Masyarakat di indonesia di masa depan yang ingin di capai melalui pembangunan kesehatan adalah masyarakat, bangsa dan negara yang ditandai oleh penduduknya hidup dalam lingkungan dan prilaku hidup sehat, memiliki kemampuan untuk menjangkau pelayanan kesehatan yang bermutu secara adil dan merata, serta memiliki derajat yang setinggi tingginya di seluruh republik indonesia. Gambaran masyarakat di Indonesia di masa depan atau dengan visi yang ingin dicapai melalui pembangunan kesehatan tersebut dirumuskan sebagai. (Ejang indan,2000)
Lingkungan yang diharapkan pada masa depan adalah lingkungan yang kondusif bagi terwujudnya keadaan sehat yaitu lingkungan yang bebas dari polusi, tersedianya air bersih, sanitasi lingkungan yang memadai, perumahan dan pemukiman yang sehat, perencanaan kawasan yang berwawasan kesehatan, serta terwujudnya kehidupan masyarakat yang saling tolong menolong dengan memelihara nilai-nilai budaya bangsa .Prilaku masyarakat Indonesia sehat 2015 adalah prilaku proaktif untuk memelihara dan meningkatkan kesehatan,mencegah terjadinya resiko penyakit, melindungi diri dari ancaman penyakit serta berpartisifasi aktif dalam dalam 
gerakan kesehatan masyarakat. |Selanjutnya masyarakat mempunyai kemampuan untuk menjangkau pelayanan kesehatan yang bermutu. Layanan yang tersedia adalah layanan yang berhasil guna dan berdaya guna yang tersebar secara merata di Indonesia. Dengan demikian terwujudnya derajat kesehatan masyarakat yang optimal yang memungkinkan setiap orang hidup produktif secara sosial dan ekonomis. Notoatmdjo soekidjo (2002)

Bank dunia mencatat sebanyak 57 juta orang di indonesia tidak mendapat akses sanitasi dasar yang layak,yaitu jamban atau sarana pembuangan limbah manusia. Sebanyak 40 juta orang diantaranya berada di wilayah pedesaan. Secara global, diperkirakan 2,5 miliar ortang di dunia tidak mendapatkan akses tersebut. Ini merupakan termasuk 1 miliar orang yang melakukan BAB disungai dan ladang. Sehingga meyebarkan virus dan kuman dari tinja melalui makanan, air, dan pakaian, keberjangkitan diare yang diakibatkan oleh hal tersebut menyebatkan kematian ribuan anak setiap harinya dan dampak-dampak negatifl lain. Seperti menghambat pertumbuhan anak. (Notoadmodjo, Soekidjo. 2007)

Pada tahun 2016 di Provinsi Sulawaesi Barat dari 291.013 kepala keluarga terdapat sebanyak 150.640 kepala keluarga yang mempunyai Jamban Sehat Permanen(JSP) dan 23.528 kepala keluarga mempunyai Jamban
Sehat Semi Permanen (JSSP) dan 100.719 yang tidak mempunyai atau Buang Air Besar Sembarangan (BABS).

(Kementerian

Kesehatan Republik Indonesia, 2016)

Pada tahun 2016 dari 99.410 kepala keluarga di Kabupaten Polewali Mandar hanya 61.433 kepala keluarga yang mempunyai Jamban Sehat Permanen (JSP) dan 2.907 yang mempunyai Jamban Sehat Semi Permanen (JSSP) dan Buang Air Besar Sembarangan (BABS). Sisanya 6.029 kepala keluarga menumpang.

\section{BAHAN DAN METODE}

penelitian ini terdiri dari atas variabel dependen dan variabel independen. Variabel dalam penelitian ini bertujuan untuk menganalisis faktor yang mempengaruhi pemanfaatan jamban keluarga di Desa Karama Kecamaan Tinambung Kabupaten Polewali Mandar

Jenis penelitian yang digunakan adalah Kualitatif dengan pendekatan fenomologi mengenai pemanfaatan jamban keluarga di Desa Karama, Kecamatan Tinambung, Kabupaten Polewali Mandar.

Populasi pada penelitian ini adalah kepala keluarga yang memiiki jamban dan kurang memanfaatkan yang ada di Desa Karama Kecamatan Tinambung Kabupaten Polewali Mandar

Penentuan sampel dipilih secara purposive sampling yaitu sampel yang diambi 
bukan tergantung pada populasi melainkan disesuaikan dengan tujuan penelitian. purposive sampling memberikan kebebasan dan peneliti dan keterikatan proses formal dalam mengambil sample

\section{HASIL}

\section{Karakteristik Responden}

Penelitian ini dilakukan di desa Karama kecamatan Tinambung Kabupaten Polewali Mandar sejak tanggal Desember 2016 sampai Februari 2017 dengan menggunakan teknik wawancara mendalam (indepth interview) berdasarkan pedoman wawancara yang telah disusun sebelumnya serta pengolahan data dan penyajiannya dalam dalam satu bulan sejak pengumuan data.

Jumlah informan yang dipilih sebanyak 11 orang terdiri dari 10 informan biasa dan 1 informan kunci (key informan) yaitu pemegang program Kesehatan Lingkungan Puskesmas Tinambung dan masyarakat desa Karama, dimana pemilihan informan yang dilakukan porfosive sampling. Adapun distribusi berdasarkan kode, alamat, umur, jenis kelamin, dan tingkat pendidikan terakhir dan pekerjaan. Untuk lebih jelasnya data dilihat pada table berikut :

Keterangan :

1. Hps, adalah merupakan informan biasa yang tinggal di Desa Karama yang berumur 40 Tahun, dan mempunyai pendidikan terakhir Sekolah Dasar (SD) pekerjaan Ibu rumah tangga.

2. Hrn, adalah merupakan informan biasa yang tinggal di Desa Karama yang berumur 62 Tahun, dan mempunyai pendidikan terakhir Sekolah Dasar (SD) pekerjaan tukang kayu.

3. Rsmn, adalah merupakan informan biasa yang tinggal di Desa Karama yang berumur 26 Tahun, dan mempunyai pendidikan terakhir Sekolah Dasar (SD) pekerjaan Ibu rumah tangga.

4. Sid, adalah merupakan informan biasa yang tinggal di Desa Karama yang berumur 45 Tahun, dan mempunyai pendidikan terakhir Sekolah Dasar (SD) pekerjaan Ibu rumah tangga.

5. Srn, adalah merupakan informan biasa yang tinggal di Desa Karama yang berumur 35 Tahun, dan mempunyai pendidikan terakhir Sekolah Dasar (SD) pekerjaan Ibu rumah tangga.

6. Arb, adalah merupakan informan biasa yang tinggal di Desa Karama yang berumur 36 Tahun, dan mempunyai pendidikan terakhir Sekolah Menengah Pertama (SMP) pekerjaan Nelayan

7. Srd, adalah merupakan informan biasa yang tinggal di Desa Karama yang berumur 42 Tahun, dan mempunyai pendidikan terakhir Sekolah Dasar (SD) pekerjaan Nelayan 
8. Hsn, adalah merupakan informan biasa yang tinggal di Desa Karama yang berumur 40 Tahun, dan mempunyai pendidikan terakhir Sekolah Dasar (SD) pekerjaan Nelayan

9. Edn, adalah merupakan informan biasa yang tinggal di Desa Karama yang berumur 37 Tahun, dan mempunyai pendidikan terakhir Sekolah Dasar (SD) pekerjaan URT

10. Dzb, adaah merupakan informan kunci yang tinggal di Majene yang berumur 39 tahun, mempunyai pendidikan terakhir (strata 1 Kesehatan Masyarakat) pekerjaan sebagai pemegang Kesling Puskesmas Tinambung kecamatan Tinambung Kabupaten polewali Mandar.

\section{Analisis Kualitatif}

a. Ras Mengenai faktor yang memengaruhi pemanfaatan jamban keluarga

\begin{tabular}{|c|c|c|c|}
\hline No & Item Pertanyaan & Pertanyaan & Hasil Wawancara \\
\hline 1 & $\begin{array}{l}\text { Tentang jamban } \\
\text { keluarga }\end{array}$ & $\begin{array}{l}\text { Hasil yang } \\
\text { diperoleh dari } \\
\text { wawancara } \\
\text { terhadap informan, } \\
\text { umumnya } \\
\text { informan } \\
\text { berpendapat } \\
\text { tentang jamban } \\
\text { keluarga adalah } \\
\text { sebagai tempat } \\
\text { penampungan } \\
\text { kotoran pada } \\
\text { petikan wawancara } \\
\text { berikut }\end{array}$ & $\begin{array}{l}\text { “...diengei tittai anna pattapung tai...." } \\
\text {..Tempat untuk membuang kotoran dan sebagai } \\
\text { penampung kotoran..(Hps) } \\
\text { “..Pattapung tai anna diengei tittai...." } \\
\text {...Tempat penampung kotoran dan tempat } \\
\text { untuk membuang kotoran }(\text { Hrn }) \\
\text { “.....Iyya diengei tittai anna pattaung tai..." } \\
\text {...Iya tempat untuk membuang kotoran dan } \\
\text { menampung kotoran.(Rsmn) } \\
\text { “...Paanna tai..." } \\
\text {...Tempat kotoran...(Sid) } \\
\text { "....Untuk diengei tittai..." } \\
\text {...Tempat untuk membuang kotoran... } \\
\text { (Hsn) }\end{array}$ \\
\hline 2. & $\begin{array}{l}\text { Mengenai } \\
\text { pentingnya } \\
\text { jamban keluarga }\end{array}$ & $\begin{array}{l}\text { Hasil dari } \\
\text { wawancara } \\
\text { terhadap informan } \\
\text { tentang pentingnya } \\
\text { jamban keluarga, } \\
\text { umumnya } \\
\text { informan mendapat } \\
\text { informasi } \\
\text { mengenai } \\
\text { pentingnya jamban } \\
\text { keluarga dari } \\
\text { petugas kesehatan.Seperti } \\
\text { pada petiakan } \\
\text { wawancara }\end{array}$ & $\begin{array}{l}\text { "...Diang biasa pole penyuluh..." } \\
\text {..sering datang petugas kesehatan melakukan } \\
\text { penyuluhan...(Hps) } \\
\text { ".....Drio dzi puskesmas anna penyuluh } \\
\text { pole..." } \\
\text {...kita dapat dari puskesmas dan petugas } \\
\text { kesehatan (Hrn) } \\
\text { "....Biasa ada datang penyuluhan dari } \\
\text { puskesmas..."(Rsmn) } \\
\text { "...biasa di ita dzilalang di televisi anna pole } \\
\text { di puskesmas...." } \\
\text {...sering kita melihat di media elektronik seperti } \\
\text { TV dan juga dari petugas kesehatan(Hsn) }\end{array}$ \\
\hline
\end{tabular}


J-Kesmas

Jurnal Kesehatan Masyarakat

\begin{tabular}{|c|c|c|c|}
\hline & & \multicolumn{2}{|l|}{ berikut: } \\
\hline & & $\begin{array}{l}\text { Hasil dari } \\
\text { wawancara } \\
\text { terhadap informan } \\
\text { tentang pentingnya } \\
\text { jamban keluarga, } \\
\text { umumnya } \\
\text { informan mendapat } \\
\text { informasi } \\
\text { mengenai } \\
\text { pentingnya jamban } \\
\text { keluarga dari } \\
\text { petugas } \\
\text { kesehatan.Seperti } \\
\text { pada petiakan } \\
\text { wawancara } \\
\text { berikut: }\end{array}$ & $\begin{array}{l}\text { Menurut informan kunci mengenai informasi } \\
\text { tentang pentingnya jamban keluarga menyatakan } \\
\text { bahwa kita memang sering melakukan pemicuan } \\
\text { terhadap masyarakat yang ada di desa karama } \\
\text { untuk merubah perilakunya seperti pada } \\
\text { penuturan berikut ini : } \\
\text { ".......mulai dari tahun } 2010 \text { itu selalu kita } \\
\text { melakukan semacam pemicuan jamban sehat tapi } \\
\text { hasilnya selama ini tidak signifikan..."(Dzb) }\end{array}$ \\
\hline 4. & $\begin{array}{l}\text { Tentang } \\
\text { perasaan jika } \\
\text { tidak memiiki } \\
\text { jamban dan tidak } \\
\text { menggunakan } \\
\text { jamban }\end{array}$ & $\begin{array}{l}\text { Apakah masyarakat } \\
\text { terlibat aktif dalam } \\
\text { mendukung } \\
\text { pelaksanaan } \\
\text { fogging? bagaimana } \\
\text { bentuk keterlibatan } \\
\text { nya? }\end{array}$ & $\begin{array}{l}\text { Bagus ji karna sebelum turun memfogging sudah } \\
\text { memangmi dikoordinasikan sama kepala } \\
\text { lingkungannya" } \\
\text { Sebenarnya justru ini permintaan masyarakat karna } \\
\text { sudah tertanammi dipikirannya kalau adami kasus } \\
\text { berarti harusmi difogging. } \\
\text { Narespon dengan baik ji karna sebelum kami datang } \\
\text { sudah memangmi najelaskan kepala lingkungannya } \\
\text { bahwa kami dari kader atau pihak dinkes sama } \\
\text { puskesmas akan memfogging daerah yang ada kasus } \\
\text { DBD nya. }\end{array}$ \\
\hline 5 . & $\begin{array}{l}\text { Tentang } \\
\text { penyakit yang } \\
\text { dialami ketika } \\
\text { tidak } \\
\text { menggunakan } \\
\text { Jamban } \\
\text { Keluarga }\end{array}$ & $\begin{array}{l}\text { Hasil yang diperoleh } \\
\text { dari informan } \\
\text { perasaan jika tidak } \\
\text { memiiki jamban dan } \\
\text { tidak menggunakan } \\
\text { jamban yaitu tidak } \\
\text { enak perasaan karena } \\
\text { kalau mau buang air } \\
\text { besar pada malam } \\
\text { hari kita buru-buru } \\
\text { lari kepantai apalagi } \\
\text { kalau sakit perut. } \\
\text { Seperti pada petikan } \\
\text { berikut: }\end{array}$ & $\begin{array}{l}\text { “......ya kadzaimi dzisading mua nandiang we apa iyya } \\
\text { dzie mua monge are mua bongi...” } \\
\text {...perasaan yang kami alami kalau kita tidak memiiki } \\
\text { WC sangat tidak enak karena ketika kita mau buang Air } \\
\text { Besar pada malam hari.(Sid) } \\
\text { “.....ya tidak enak apalagi mua udzammi mua kadzao } \\
\text { bongi cappumi tau base mua maendo saui tau } \\
\text { dzisasi....” } \\
\text {...perasaan tidak enak karena kalau hujan dan jauh } \\
\text { malam kita terpaksa lari ke pantai samai basah (Arb) } \\
\text { “......indani macao apa iyadzio mua mongei are kadzao } \\
\text { bongi...” } \\
\text {..Itu idak bagus kerena kau ketika kita mau buang Air } \\
\text { Besar pada malam hari(Srn) }\end{array}$ \\
\hline 6. & Tentang & Berdasarkan & ".....amongeang monge adze..." \\
\hline
\end{tabular}


J-Kesmas

Jurnal Kesehatan Masyarakat

\begin{tabular}{|c|c|c|}
\hline $\begin{array}{l}\text { penyakit yang } \\
\text { dialami ketika } \\
\text { tidak } \\
\text { menggunakan } \\
\text { Jamban } \\
\text { Keluarga }\end{array}$ & $\begin{array}{lr}\text { informasi } \\
\text { wawancara } \\
\text { bersama informan } \\
\text { penyakit } & \text { yang } \\
\text { dialami } & \text { ketika } \\
\text { tidak } & \text { memakai } \\
\text { jamban } & \text { keluarga } \\
\text { yaitu umumnya } \\
\text { informan } \\
\text { mengalami } \\
\text { penyakit } \\
\text { perut seperti pada } \\
\text { penuturan berikut } \\
\text { ini: }\end{array}$ & $\begin{array}{l}\text {...penyakit yang kami rasakan yaitu sakit perut..(Srn) } \\
\text { “......sakit perut anna mencret...”. } \\
\text {....Sakit perut dan mencret(Arb) } \\
\text { “....sakit perut anna muntah-muntah..”. } \\
\text {..Sakit erut dan muntah-muntah...(Hsn) } \\
\text { Adapun informan kunci mengatakan penyakit yang } \\
\text { timbul ketika Buang Air Besar tidak menggunakan } \\
\text { Jamban Keuarga yaitu sakit perut, diare, dan tipoid } \\
\text { seperti pada petikan wawancara berikut : } \\
\text { “......peyakit diare dan tipoid dan itu faktor lingkungan } \\
\text { dan kondisi sanitasi...”(Dsb) }\end{array}$ \\
\hline $\begin{array}{l}\text { Tradisi } \\
\text { mengenai faktor } \\
\text { yang } \\
\text { memengaruhi } \\
\text { pemanfaatn } \\
\text { jamban keluarga }\end{array}$ & $\begin{array}{l}\text { Hasil yang } \\
\text { diperoleh dari } \\
\text { wawancara } \\
\text { terhadap informan } \\
\text { mengenai buang } \\
\text { air besar di pantai } \\
\text { umumnya } \\
\text { informan } \\
\text { mengatakan bahwa } \\
\text { buang air besar di } \\
\text { pantai lebih } \\
\text { nyaman dan juga } \\
\text { sebagai pelarian }\end{array}$ & $\begin{array}{l}\text { “.....manyamani perasaannu mua dzilai dzi sasi dari } \\
\text { wc....” } \\
\text {...kami merasa nyaman Buang Air Besar di pantai } \\
\text { daripada WC..(Hsn) } \\
\text { “.....mua siparai tau melo tittai jadzi maendmbmi sau } \\
\text { tau dzi sasi....” } \\
\text { Apabila kita bersamaan mau Buang Air Besar terpaksa } \\
\text { ada yang lari di pantai...(Edn) } \\
\text { “...merasa nyaman dan tidak repot...”(Arb) }\end{array}$ \\
\hline $\begin{array}{l}\text { Tentang tidak } \\
\text { merasa malu jika } \\
\text { Buang Air Besar } \\
\text { di pantai }\end{array}$ & $\begin{array}{l}\text { Hasil wawancara } \\
\text { yang diperoleh dari } \\
\text { informan mengenai } \\
\text { tidak merasa malu } \\
\text { Buang air Besar di } \\
\text { pantai umumnya } \\
\text { informan } \\
\text { menjawab tidak } \\
\text { merasa malu } \\
\text { karena sudah } \\
\text { menjadi kebiasaan } \\
\text { selama ini }\end{array}$ & $\begin{array}{l}\text { “ya tidak merasa malu karna sudah kebiasaan dzisasi } \\
\text { anna mayamang toi tappa maendong sau dzisasi...” } \\
\text {....itu sudah kebiasaan kita Buang Air Besar di pantai } \\
\text { dan itu membuat kami nyaman dan kita langsung lari } \\
\text { kesana ketika kita mau Buang Air Besar (Arb) } \\
\text { “.......anndammi tau masiri mau dziang tau dzio } \\
\text { maccurita dzio dzisede andammi dzijapangngi saba } \\
\text { kebiasaan mo...” } \\
\text { kami tidaki merasa malu walaupun ada orang bercerita } \\
\text { didekat kita kami tidak perdulikan lagi karena itu sudah } \\
\text { kebiaasan (Srd) } \\
\text { “.....Indammi tu'u tau masiri apa kebiasaan mo....” } \\
\text {..kami tidak merasa malu karena itu sudah tradisi atau } \\
\text { kebiasan }(\text { Hrn) }\end{array}$ \\
\hline Tentang & Adapun & $\begin{array}{l}\text { ".....sanggin dziang nyamanna mua lai dzisasi tamppa } \\
\text { saumi tau micoko andammi tau massau uwai..." }\end{array}$ \\
\hline
\end{tabular}


J-Kesmas

Jurnal Kesehatan Masyarakat

\begin{tabular}{|c|c|c|}
\hline $\begin{array}{l}\text { perasaan buang } \\
\text { air besar di } \\
\text { pantai dari pada } \\
\text { di jamban } \\
\text { keluarga }\end{array}$ & $\begin{array}{l}\text { wawancara yang di } \\
\text { dapat dari } \\
\text { informan tentang } \\
\text { perasaan buang air } \\
\text { besar di pantai dari } \\
\text { pada di jamban } \\
\text { keluarga umumnya } \\
\text { informan } \\
\text { mengatakan baik di } \\
\text { pantai dari pada di } \\
\text { jamban keluarga } \\
\text { karena kalau di } \\
\text { pantai tidak terlalu } \\
\text { bau }\end{array}$ & $\begin{array}{l}\text {.... semua itu ada kekurangan dan kelebihannya kalau } \\
\text { kita Buang Air Besar di pantai kita tidak repot lagi untuk } \\
\text { ambil air atau menimba (Hrn) } \\
\text { “... Kan luas banyak air tidak repot pokoknya nyaman } \\
\text { kalau dzi sasi....” } \\
\text {...Pantai itu luas banyak air pokonya nyaman kalau kita } \\
\text { Buang Air Besar di pantai.. (Arb) } \\
\text { “.....Kalau di pantai sudah terbiasa anna mua we } \\
\text { andangi tau terbiasa jadzi manyangi mua dziai } \\
\text { dzisasi...”(Rmn) }\end{array}$ \\
\hline $\begin{array}{l}\text { Tentang alasan } \\
\text { masih sering } \\
\text { buang air besar } \\
\text { di pantai }\end{array}$ & $\begin{array}{l}\text { Adapun hasil } \\
\text { wawancara dari } \\
\text { informan tentang } \\
\text { alasan masih sering } \\
\text { buang air besar di } \\
\text { pantai umumya } \\
\text { informan } \\
\text { mengatakan bahwa } \\
\text { mengapa di pantai } \\
\text { karena tidak terlalu } \\
\text { bau }\end{array}$ & $\begin{array}{l}\text { “.....panno manini bak mua simata tiitai dzini tau jadzi } \\
\text { sekali-kali dzio dzisasi...” } \\
\text { (Edn) } \\
\text { “....manyamangi mua lai dzisasi apa indani } \\
\text { sarombong leba anna kebiasaan tomo...” } \\
\text {...pantai membuat kami nyaman kerena tidak terlalu } \\
\text { bau dan juga sudah menjadi kebiasaan.. (Hsn) }\end{array}$ \\
\hline
\end{tabular}

\section{PEMBAHASAN}

\section{Ras mengenai faktor yang memengaruhi}

\section{pemamfaatan jamban keluarga}

\section{a. Tentang jamban keluarga}

Ras adalah kategori untuk sekelompok individu/manusia yang secara turun-temurun memiliki ciri fisik dan ciri biologis yang sama. Dalam klasifikasi mahluk hidup, sekelompok manusia merupakan satu spesies, yaitu homo sapiens. Kelompok manusia yang satu spesies tersebut secara biologis dapat diklasifikasikan kedalam beberapa kelompok yang lebih kecil (genus), inilah yang disebut ras. Sampai dimana masyarakat Ras atau suku Mandar

mengetahui tentang jamban keluarga. Indikator pertama yang harus kita ketahui bagaimana pengetahuan suku mandar mengenai jamban keluarga.

Berdasarkan penelitian terhadap informan tentang jamban keluarga di Desa Karama Kecamatan Tinambung Kabupaten Polewali Mandar umumnya masyarakat mengetahui tentang jamban keluarga bahwa jamban 
J-Kesmas

Jurnal Kesehatan Masyarakat

keluarga sebagai tempat penampungan tinja atau kotoran

Menurut (Notoadmojo 1996) pembungan tinja merupakan salah satu upaya kesehatan lingkungan yang harus memenuhi sanitasi dasar bagi setiap keluarga. pembuangan kotoran yang baik harus dibuang ke dalam tempta penamungan kotoran yang disebut dengan jamban. Jamban adalah suatu bangunan yang digunakan untuk membuang dan mengumpulkan sehingga kotoran itu tersiman dalam suatu tempta tertentu dan tidak menjadi sarang penyakit.

\section{b. Tentang pentingnya jamban keluarga}

Jamban keluarga adalah suatu ruangan yang mempunyai fasilitas pembuangan kotoran manusia yang terdiri dari atas tempat jongkok atau tempat duduk dengan leher angsa atau tanpa leher angsa (cemplung) yang dilengkapi dengan unit penamungan kotoran dan air untuk membersikanya, agar supaya tidak mengundang datangnya lalat atau serangga yang dapat menjadi penular penyakit seperti diare, dan kecacingan ${ }^{\mathrm{i}}$

Berdasarkan penelitian menurut informan informasi mengenai pentingnya jamban keluarga diketahui umumya mengemukakan dari petugas kesehatan dan media elektronik dan tetangga.

\section{c. Tentang perasaan jika tidak memiiki jamban dan tidak menggunakan jamban}

Perasaan masyarakat ketika tidak menggunakan jamban keluarga dan tidak menggunakan jamban keluarga sangat tidak enak karena disaat mereka mau buang air besar pada malam hari sangat meresahkan disaat cuaca tidak mendukung pada malam hari.

Berdasarkan penelitian menurut informan perasaan mereka pada saat tidak memiliki jamban keluarga dan tidak menggunakan jamban keluarga umumnya mengemukakan sangat meresahkan apabila ingin buang air besar pada malam hari

\section{d. Penyakit apa yang bapak/ibu rasakan} jika tidak menggunakan jamban keluarga.

Buang air besar merupakan bagian yang penting dari ilmu perilaku dan kesehatan masyarakat. Pembuangan tinja yang memenuhi syarat merupakan sautu kebutuhan kesehatan masyarakat yang selalu bermasalah setidaknya sampai saat ini diakibatkan perilaku buang air besar yang tidak sehat. Perilaku

Buang air besar yang tidak sehat yang menjadi saran penularan penyakit.

Berdasarkan penelitian menurut informan penyakit yang dialami ketika tidak menggunakan jamban keluarga 
umumnya mengemukakan yaitu penyakit sakit perut.

Menurut Notoatmodjo (2007), jamban atau latrine merupakan tempat pembuangan kotoran manusia baik tinja maupun air seni. Kotoran manusia ( feces) adalah sumber penyebaran berbagai macam penyakit seperti tifus, disentri, kolera, bermacam-macam cacing (gelang, kremi, tambang, pita). Sedangkan menurut Suyono dan Budiman (2011) beberapa penyakit yang dapat ditularkan melalui tinja manusia diantaranya kholera, disentri, tifus, abdominalis, polio mielitisanterior akuta, hepatitis infeksi, cacingan, antraks, skistosomiasis atau legionelosis.

\section{Tradisi mengenai faktor yang}

\section{memengaruhi pemanfaatn jamban}

\section{keluarga Tentang buang air besar di} pantai.

Tradisi adalah kesamaan benda material dan gagasan yang berasal dari masa lalu namun masih ada hingga kini dan belum dirusak. Tradisi dapat diartikan sebagai warisan yang benar atau warisan masa lalu. Namun demikian taradisi yang terjadi berulang-ulang bukanlah dilakukan secara kebetulan atau atau disengaja.

\section{a. Tentang Buang Air Besar di pantai}

Selama berpuluh-puluh tahun mereka melakukan kebiasaan tersebut tanpa menyadari perilaku itu sebenarnya mengundang penyakit.

Berdasarkan penelitian informan membuang air besar di pantai umumya mengugkapkan sangat nyaman dari pada buang air besar di WC karena tidak repot-repot lagi untuk cebok. Dan tidak terlalu bau.

\section{b. Tentang tidak merasa malu jika} Buang Air Besar di pantai

Masyarakat tidak merasa malu lagi membuang Air Besar di pantai karena sudah kebiasaan dalam turun-temurun. Kebiasaan itu timbul karena proses penyusutan kecendrungan respon dengan menggunakan stimulasi yang berulangulang. Karena proses penyustan/pengurangan inilah, muncul suatu pola bertingkah laku baru yang relative menetapdan otomatis.mengubah kebiasaan adalah sebuah hal yang terlihat sepeleh,tetapi sangat sulit jika ingin kita lakukan.

Berdasarkan penelitian informan tentang tidak merasa malu jika Buang Air Besar di pantai umumya mengemukakan bahwa tidak merasa malu karena sudah kebiasaan atau sudah tradisi kita lakukan dan sudah turun temurun. 
c. Tentang perasaan Buang Air Besar di pantai dari pada di jamban keluarga

Buang Air besar di pantai semuanya mempunyai kekurangan dan kelebihan seperti yang di alami masyarakat dalam Buang Air Besar di pantai maupun di WC.

Berdasarkan penelitian informan tentang Buang Air Besar di pantai dari pada di WC umumya informan mengemukakan membuang air besar di pantai sangat nyaman di banding di WC dan juga kami tidak repot lagi dan juga tidak terlalu bau.

\section{d. Tentang alasan masih sering buang air besar di pantai}

Alasan mengapa masyarakat masih sering Buang Air Besar di pantai dikarenakan takutnya tabung bak kotoran tidak cepat penuh dan ketika juga mau bersamaan Buang Air Besar salah satunya ke pantai dan kalau di pantai juga lebih nyaman dan sudah kebiasaan.

Berdasarkan penelitian terhadap informan tentang alasan masih sering Buang Air Besar di pantai umumya mengemukakan itu sudah kebiasaan meskipun kita mempunyai WC karena di pantai juga tidak terlalu bau.

e. Tentang tidak akan Buang Air Besar di pantai jika mempunyai jamban keluarga
Mengenai tidak akan Buang Air Besar di pantai jika mempunyai jamban keluarga itu yang dikemukakan oleh informan yang tidak mempunyai jamban keluarga tetapi informan yang mempunyai jamban keluarga masih sering Buang Air Besar di pantai karena sudah kebiasaan mereka.

Berdasarkan penelitian terhadap informan tentang tidak akan Buang Air Besar di pantai kalau sudah mempunyai jamban keluarga umumya mengemukakan tidak lagi Buang Air Besar di pantai ketika sudah mempunyai jamban keluarga.

\section{KESIMPULAN}

Berdasarkan hasil penelitian sebagaimana yang telah diuraikan ada pada Bab sebelumnya maka dapat ditarik beberapa kesimpulan bahwa :

Ras pemahaman masyarakat suku mandar mengenai jamban keluarga masih kurang dan mengenai fungsi jamban keluarga,meskipun petugas kesehatan selalu melakukan pemicuan, tetapi untuk implementasi masih kurang karena faktor kebiasaan dan lingkungan yang berdekatan dekat pantai. Sehingga perilaku masyarakat untuk Buang Air Besar di pantai sangat sulit untuk kita hilangkan. 
J-Kesmas

Jurnal Kesehatan Masyarakat

Tradisi masyarakat suku mandar mengenai Buang Air besar di pantai itu sudah turun-temurun karena sudah kebiasaan dan membuat mereka nyaman dengan lingkungan di pantai di banding di WC. Buang Air Besar di pantai membuat mereka sangat enjoi Buang Air Besar di pantai karena tidak terlau bau.

\section{SARAN}

Kepada pihak pemerintah setempat untuk membuat peraturan desa mengenai Buang Air Besar Sembarangan,untuk deberikan sangsi/denda bagi masyarakat yang masih melakukan Buang Air Besar sembarangan di pantai supaya perilaku atau kebiasaan mereka bisa berubah.

Disarankan kepada petugas kesehatan terkhusus pemegang program Kesehatan Lingkungan untuk meningkatkan penyuluhan mengenai pemamfaatan jamban keluarga utamanya di Desa Karama Kecamatan Tinambung

\section{UCAPAN TERIMA KASIH}

Terima kasih kepada kedua orang tua dan keluarga yang memberikan seluruh bantuan dan dukungan dalam menyelesaikan penelitian ini. Serta Camat Wonomulyo yang telah memberikan izi untuk penelitian ini.
Ejang indan,(2000)"Ilmu Kesehatan Masyarakat" Bandung: PT Cira Aditya

Notoatmdjo soekidjo (2002) Metode penelitian kesehatan, Jakarta, penerbit Rineka Cipta

Sugiyono, (2008)"pendekatan Kualitatif ,Kuantitatif dan R\&G “ bandung buku penelitian pendidikan

Fakultas kesehatan Masyarakat Universias AlAsyariah Mandar Polewali Mandar ,(2016)" pedoman penulisan Skripsi "Unasman

Notoadmodjo, Soekidjo. 2007. Promosi Kesehatan dan Ilmu Perilaku. Rineka Cipta. Jakarta 2016.

Kemenkes-RI. Peraturan Mentri Kesehatan Republik Indonesia Nomor:374/Menkes/Per/III/2010. Jakarta: Direktorat Jendral PP dan PL kemenkes RI;2012

Kementerian Kesehatan Republik Indonesia, 2016. www.kemkes.go.idProfil PP dan PL Tahun 2014 Ditjen Kemkes. Diakses 23 Mei 2016.

World Health Organisation. (2016). Dengue and severe dengue. fact sheet. Upadted July 2016. Word Health Organization, http://www.who.int/mediacentre/factsheet s/fs117/en. https://doi.org/10.1111/14690691.1244

\section{DAFTAR PUSTAKA}

